術前診断し壳た腸壁囊状気腫の 1 治験例

\begin{tabular}{|c|c|c|c|c|}
\hline & & 厚生中的 & 病院外和 & \\
\hline 㫐澤 & 博久 & 今井 & 直人 & 雚 \\
\hline 邽口 & 明宏 & 櫻井 & 秀樹 & 佐野 \\
\hline
\end{tabular}

\title{
A CASE REPORT OF PNEUMATOSIS CYSTOIDES INTESTINALIS WITH SUCCESSFUL PREOPERATIVE DIAGNOSIS
}

\author{
Hirohisa KUMAZAWA, Naoto IMAI, Seiken SAI, \\ Akihiro NOGUCHI, Hideki SAKURAI and Kanji SANO
}

Dept. of Surgery, Kosei Chuo General Hospital

索引用語：腸壁爰状気重, 左半結腸切除術, 間歇的酸素療法

\section{はじめに}

腸壁囊状気腫は, 腸管壁内に多数の含気性の裹状気 腫が発生する比較的尗な疾患であり，術前に診断の 確定した症例は少ない，今回われわれは，下剕，メレ ナ，腹痛を主訴とした左横行結腸から直腸に至る本症 を経験した．左半結腸切除術と間歇的酸素療法にて治 瘑せしめたので, 経過の概要を述べ若干の文献的考察 を加えて報告する。

$$
\text { 症例 }
$$

患者：吉 $\bigcirc, 79$ 歳, 男性.

主訴：下疡，メレナ，腹痛。

既往歷: 69歳時, 胆石症の手術. 72 歳時飞総胆管拡 張症の手術.

現病歴：昭和59年 2 月初旬より上記の主訴が出現 し，症状の軽状がみられず緊急入院した。

入院時所見：1日 $5 \sim 6$ 行の粘血便を伴ら下浰を認 めた。体格栄養は中等度. 腹部所見として腫瘤を触知 せず，筋性防禦もなかったが，左側腹部に圧痛を認め た. 末梢血液, 生化学的所見並びに理学的所見に異常 を認めない。

腹部単純写真 : 左上腹部から下腹部に至る広範囲の 部分に，大小さまざまな無数のガス像（あたかもブド ウの房状に密集した）を認めた（図 1).

注腸造影所見：充盈像では特に上部直腸から下行結 腸にかけてヒイラギ葉様の陰影欠損像がみられ（図 2

$<1985$ 年 4 月 17 日受理 $>$ 別刷請求先：熊澤 博久

₹153 目黒区三田 1-11-27 厚生中央病院外科
因 1 腹部単純写真 (立位) 左腹部にブドゥ房状に密集した著明なガス像をみる。

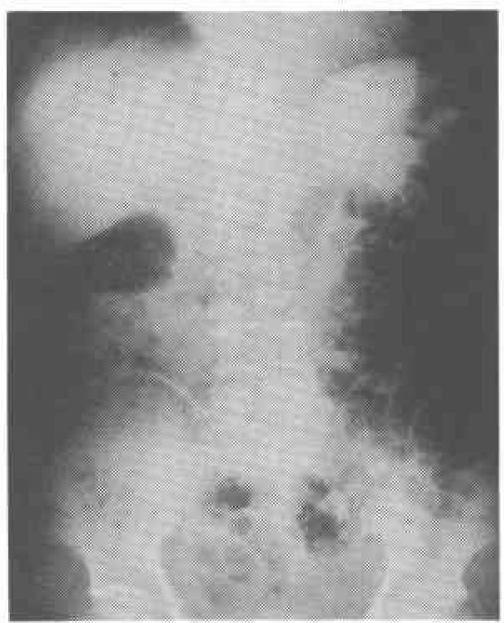

一左), 二重造影では円形または楕円形の大小不同の無 数の隆起性病变を, 左横行結腸まで認めた(図 2-右). 内視鏡所見：下部直腸より中枢側に半球状，表面平 滑な無数の隆起性病変が確認され, 多くの粘膜は健康 部と色調は変わらないが, 一部の粘膜表面に発赤, び らんがみられた（図了）。

その注か, 上腸間膜動脈撮影，下腸間膜動脈撮影な ぞを施行した。諸検査から悪性腫瘍，潰瘍性大腸炎， 阻血性大腸炎などを否定し，本症と術前診断した。症 状の改善がみられず，病変の広範囲に及んでいること などから手術適応とした。 
図 2 注腸造影写真

左：充盈像. 苴腸から下行結腸にヒイラギ葉様の陰 影欠損像をみる。右：二重造影像. 大小不同の無数 の隆起性病変をみる.

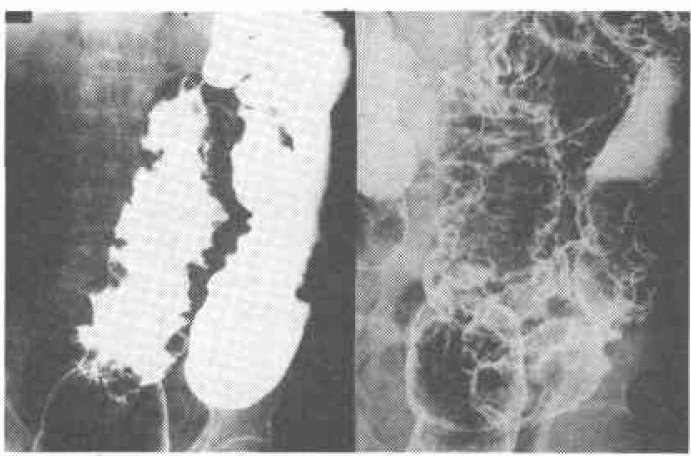

図 3 内視鏡像 半球状の表面平滑な隆起性病変をみる。

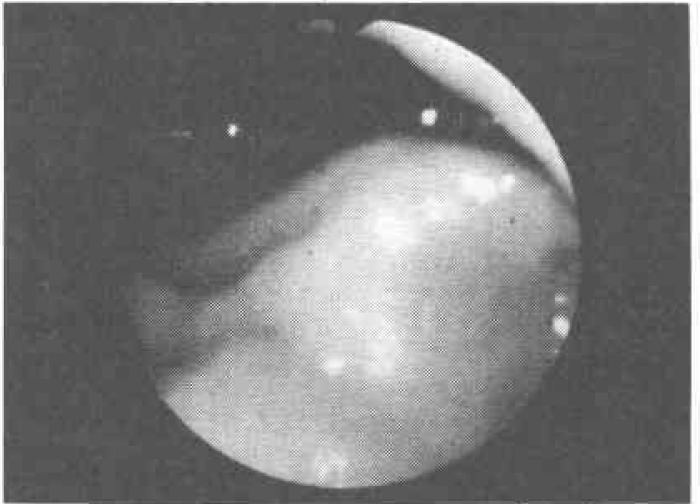

手術所見：左傍腹直筋切開で開腹. 直腸の腹膜翻転 部より左横行結腸にかけて, 大小無数の弾力性ある腫 瘤を采膜側から触知できた。

また浆膜側にも多数の噰胞状の気腫を認めた。左半 結腸切除術（端々伆合）を施行した。

切除標本所見：粘膜面には粘膜䀜壁に沿うように大 小不同の無数の半球状の隆起がみられ，表面の一部に 小出血，びらんがみられた(図 4 )。割面では図 5 に示 すごとく，粘膜面から浆膜面の脂肪組織に至るまでの 全腸管壁に, 大小さまざまの内腔を有する襄状気腫と 気腫が存在している。液体内容はなかった。

病理組織所見：粘膜筋板の寸ぐ下, submucosa に多 くの隻状気腫が形成され，筋層には余り変化はない. 大きいCyst を形成した所では，その壁構造は結合織 性で, 襄状気腫内面に小数の多核巨細胞がみられ，上
図 4 切除標本

粘膜雅璧に沿って, 大小不同の多数の半球状の隆起 性腫瘤をみる。

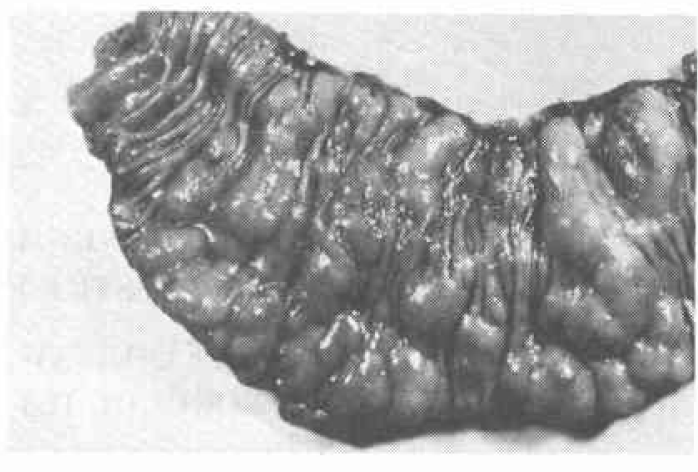

図 5 固定標本の割面 粘膜下に大小無数の襄状気腫が存在し(上段)，また 採膜脂肪組織にも多房性気腫を認める（下段）。

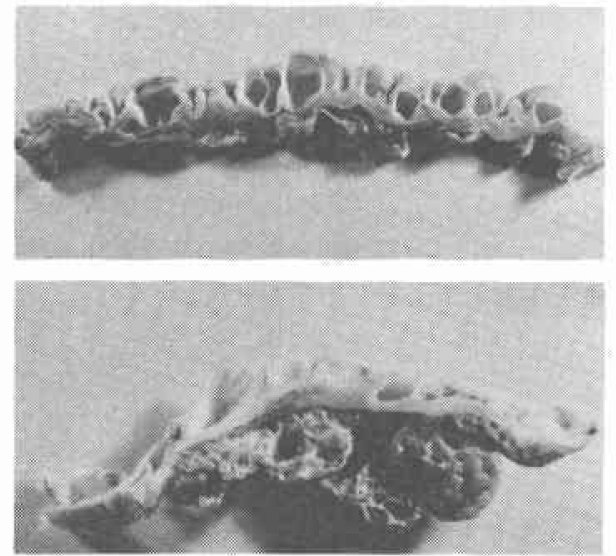

皮被覆ははっきりしない(図 6).

しかし小さい囊状気腫をみると，薄い蛋白液が残っ ており，喰細胞様のものが壁に附着している（図6挿 入写真, 図 7). 壁構造は脈管を暗示する所見,すなわ ち種々の特殊染色で弾力線維の残存が認められ，成因 としてのリンパ管の閉塞を示唆する所見が党られた (図 7 ). 更に症例がえられれば，今後の検討にまちた い.

術後経過：下部直腸に残存した囊状気腫は，鼻孔力 ニニーレ, マスクによる 1 日 $6 \sim 3$ 時間, $\mathrm{O}_{2} 5 \sim 1 l /$ 分 の間歇的酸素療法 9 日間の実施で完全に消失した。現 在術後 9 力月を経過したが，再発傾向はなく，日常生 活に復帰している。 
図 6 病理組織所見 (1)

粘膜筋板の寸ぐ下, submucosa に大きな震状気腫が 形成されている $(\mathrm{HE} . \times 40)$. 插入写真は小さい囊状 気腫の強抎大 (PAS. $\times 400)$.

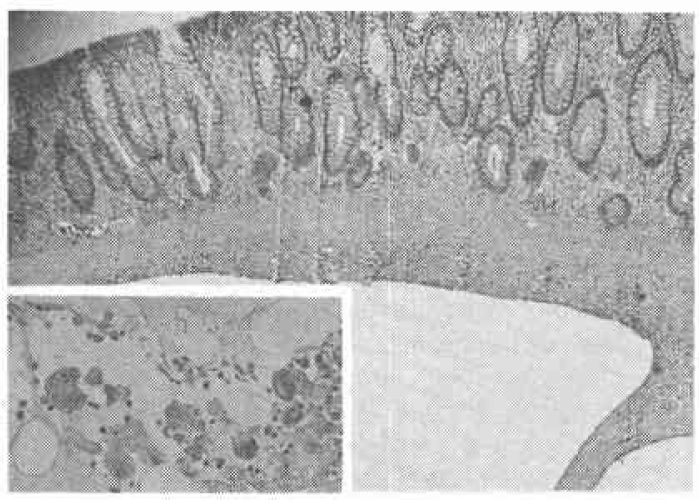

図 7 病理組織所見 (2)

小さい震状気腫には，薄い蛋白液が残こり，喰細胞 様のものが壁に附着し, 壁構造は弾力線維の残存が 認められる。

左：エラスチカ・ワンギーソン染色 $(\times 100)$. 右： アザン・マロリー染色 $(\times 100)$.
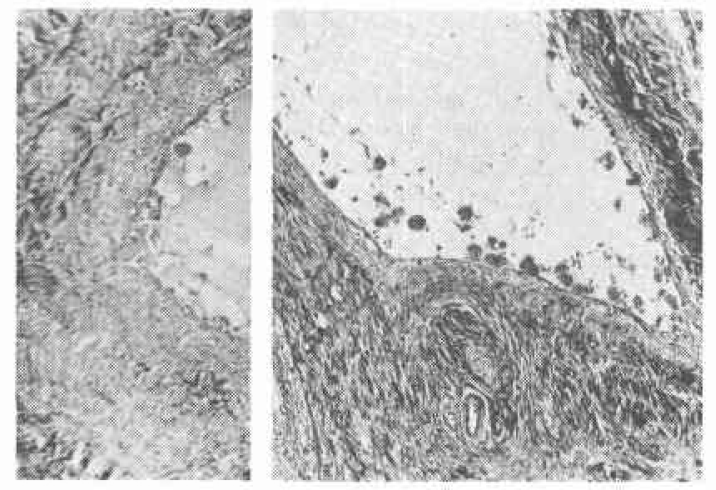

考察

腸壁糞状気腫は内外の文献に多くの報告がみられる が,しかし日常の診療に際してはまれな疾患と考学る。

本症は1825年 Mayer ${ }^{1}$ が膦の小腸に発見し, Pneumatosis cystoides intestinorum の名称を初めて 記載し, 1876年 $\mathrm{Bang}^{2)}$ が最初に屍体解剖で本症を詳細 に報告したとされている。一方, 本邦では1901年三輪3 が剖検時に発見し報告したのが最初である。

発生部位は, $\mathrm{Koss}^{4}$ が213例の本症について検討し, 小腸発生例に比し大腸のものわずか13例と報告した. 小腸に括いては特に回腸に好発すると和崎(5), 江里ら は報告している。しかし最近では, 大腸に発生する頻
度の多いことが報告7) 9)されており, 特に左結腸に多

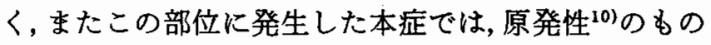
といわれている。

男女比並びに発症年齢では，Koss'的による統計では $3.5: 1$, 和崎ら 5 の集計では39:17と男に多いと報告 している.しかし最近の大西ら ${ }^{99}$ 集計では21：39と 女性の報告例が増加している、発症年齡は大西" によ れば，1歳以下15例，40歳代17例，60歳代11例と小児， 中年ならび高齢者にその発生頻度が高いと述べ，特に 小腸発生は女性に，また高龄者に多いことが興味ある と報告している.

発生原因についてはなだ一定したものはない. 従来 より腫瘍説, 栄盖障害説, 循環障害説, 化学説, 細菌 説，機械説，肺原説と種々挙げられているが，今日ま では細菌説, 機械説, 肺原説の可能性が示晙されてい る. 細菌説はガス産生の細菌が腸壁内に侵入し, 本症 が発生するといらもので, 乳幼児に発症する壊死性腸 炎に高率に合併しているとして受け入れられている。 特に術後の合併症として, 曠置された小腸の機能不全 と蠕動の欠如により嫌気性菌が増殖し，それが粘膜下 に侵入しそこでガス産生したと説明している報告1112) あある。これを裏付ける実験として, Yale ら ${ }^{13) 14)}$ は無 菌ラットの腸壁に clostiridium perfringensを注入す ることにより，容易に本症をみたといい，嫌気性ガス 産生菌による本症の細菌説を示唆している。しかし臨 床面で局所の炎症所見がみられないこと, 囊状気腫内 の細菌を証明できないことなどから否定的な意見すあ る. 実際われわれる術中に襄状気腫内の細菌を検索し たが，証明されずに終っている，機械説は幽門狭窄， 腸閉塞などがあると胃腸の内圧が上昇し，腸管の内の ガスが腸粘膜の間隚よりリンパ管などに侵入して発 生 ${ }^{15)}$ するいうすのである.肺原説は閉塞性肺疾患, 慢 性肺疾患などで咳嗽時に肺胞の裂隌より侵入したガス が，綎隔を経由して後腹膜，腸間膜，腸管壁に達する というものである ${ }^{16)}$.

症状は小腸例では他疾患の開腹時，剖検時に発見さ れることが多く，特有な症状のないことが多い，悪心 呕吐 ${ }^{6)}$, 腹部膨満感6), 下腹部不快感, などである。し かし大腸例では腹痛(6)12)17)，便秘，下而 ${ }^{12)}$ ，メレナなど の症状が強い場合が多い.

術前診断は困難な場合が多いが，大腸例では腹部の 単純写真で，大小さまさまなブドウ房状に密集したガ ス像や，小円形蜂窩状のガス像が特徴的である。注腸 造影検查では，われわれの症例のごとく充盈像で震状 
気腫による陰影欠損のヒイラギ葉状像がみられ，二重 造影では大小不同の多数の裹状気廆を示す隆起性病変 がみられるのが特異的である，大腸内視鏡検査では， 腸管全周性に多発している表面平滑な半球状の隆起性 病変を確認できる。この部の生検所見の報告 ${ }^{18)}$ や, boring biopsy で小襄腫様の变化がみられたとの報告 ${ }^{17)}$ あり，診断上参考になる。

治療は小腸に発生したものでは自然治癒もあるが, 狭窄，出血などの合併症がなければ，保存療法が望ま しいとされてきた。しかし，大腸に発生したものでは 自然治癒の報告 ${ }^{19)}$ もるが, 頻回の腹痛,メレナなど主 訴の強いものや，広範囲の部位に及ぶものでは腸切除 される場合が多い(18)20)，最近では Forgas ${ }^{21)}$ の報告以 来, 本症に対する酸素療法が注目され実施911722223)され ている. 本療法のメカニズムは不明な点もあるが, 高 濃度の酸素の吸入により動脈血中の $\mathrm{PaO}_{2}$ が上昇し, この酸素と虽状気腫内のガスの主成分である窒素と置 換し，置換された酸素は組織に吸収され，代謝作用に より気腫が消失するというすのである，われわれの症 例は左半結腸切除を施行したが，広範囲のため下部直 腸に残った数個の变状気腫に, 間歇的酸素療法を 9 日 間施行し完全に消失した。酸素療法による再発例の報 告 ${ }^{2223)}$ むるが, $\mathrm{PaO}_{2} 200 \sim 300 \mathrm{mmHg}$ 程度に上昇せ

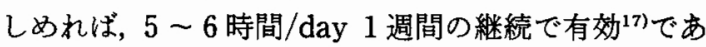
るといら。今後, 症例によっては適応を選び推奖しら る方法である。

\section{おわりに}

79歳の高齢者男子の広範囲にわたる腸壁囊状気稙に 対し, 術前診断し左半結腸切除術々間歇的酸素療法を 施行した治験例を経験した。症例の経過の概要を述べ， 若干の文献的考察を加光て報告した.

稿を終るに際し，中検病理大泹サチ博士の協力を感謝す る.

\section{文 献}

1) Mayer B: Beobachtung einer Pneumatosis cystoides intestinorum. Hufelands S J Pract Heilk 61 (pt. 2)：67，1825，(文献15)より引用)

2) Bang BLF: Lustholdige kyster i văggen af ileum ag i nydannet bindeväv pä sammes serosa. Nord Med Ark 8, 18:1-15, 1876 (文献15) およびBaer $S$ et al: Pneumatosis cystoides infestinalis. Med Klin 67：1731-1735，1982より 引用)

3）三輪徳寛 : Úber einer Fall von Pneumatosis cystoides intestinorum huminis. 261 Chir 28 : 427-428, 1901

4) Koss LG: Abdominal gas cysts (Pneumatosis cytoides intestinorum hominis): An analysis with a report of a case and a critical review of literature. AMA Arch Pathol Lab Med 53: 523-549, 1952

5）和崎昭雄, 佐伯壮六, 安田光則汪か：腸管囊腫様気 畽の 1 例. 長畸医会誌 $38: 551-556,1963$

6）江里健輔，佐利厚生，有好邦夫注か：腸管裹腫様気 腫 (Pneumatosis cystoides intestinalis) の 1 例 一本邦報告例の統計的観察一。外科治療 10 : 1641-1644, 1968

7) Smith BH, Usn CMC, Weffer LH: Pneumatosis intestinalis. Am J Clin Path $48: 455-465$, 1967

8) Varano VJ, Bonanno CA: Colonoscopic findings in pneumatosis coli. Am J Gastroenterol $59: 353-360, \quad 1973$

9）大西和彦，淵本定儀，光花孝文法か：術後吻合部に 発生を繰り返した腸壁整腫状気腫の 1 例一および 本邦報告例の統計的観察一, 日消外会誌 17 : 1615-1618, 1984

10) Prist RJ: Pneumatosis cystoides intestinalis. Gastroentsrology Vol II, 1099, Edited. by. Bock. us Philadelphia, London, Toronto W B Saunders Co, 1976

11) Menguy R: Pneumatosis intestinalis after jejunoileal bypass : Etiological mechanism in one case. JAMA $236: 1721-1723,1976$

12) Wilson SE, Passaro E: Pneumatosis intestinalis. JAMA $236: 559,1976$

13) Yale CE, Balish E, Wu JP: The bacterial etiology of pneumatosis cystoides intestinalis. Arch Surg 109:89-94, 1974

14) Yale CE, Balish E: Pneumatosis cystosides intestinalis. Dis Colon Rectum 19:107-111, 1976

15) Stiennou OA: Pneumatosis intestinalis in the newborn. AMA Am J Dis Child $81: 651-663$, 1951

16) Keyting WS, McCarver R, Kovarik JL et al: Pneumatosis intestinalis. A new concept. Radiology $76: 733-741,1961$

17）姝尾恭一, 大久保卓次, 長谷川晴喜仿: 酸素療法 が著効を示した pneumatosis coli の 1 例. 胃と腸 $19: 1035-1040,1984$

18）㮖木野修郎, 宮崎範文, 大塚 量洁か：腸管䨢嗹様 気腫の 1 例. 日消病会誌 $77: 451-454,1980$

19）小田和金重, 山崎岐男, 田代成元：腸管垔腫様気腫 の 1 例. 臨放線 $19: 715-721 ， 1974$

20）寺島文平, 菅谷 昭, 䈷原光男注か：晹管震腫様気 腫の 1 例. 外科診療 $15: 356-358,1973$

21) Forgacs $P$, Wright $P H$, Wyatt AP: Treatment of intestinal gas cysts by oxygen breathing. Lancet 1: 579-582, 1973

22) Masterson J : Treatment of pneumatosis coli with hyperbaric oxygen. Ann Surg 187 : 245-247, 1978

23) Holt $\mathrm{S}$, Gilmour HA, Buist TAS et al: High flow oxygen therapy for pneumatosis coli. Gut $20: 493-498,1979$ 